\title{
ISOLATED ADRENOCORTICOTROPIC HORMONE (ACTH) DEFICIENCY ASSOCIATED WITH HASHIMOTO'S DISEASE
}

\author{
Emine Binnetoğlu, Mehmet Aşık, Hacer Şen, Fahri Güneş, Erdem Akbal, Zeliha \\ Tekeli, Betül Kızıldağ, Kubilay Ukinç
}

\section{Introduction}

Isolated ACTH deficiency (IAD) is a rare disease which is characterized by secondary adrenal insufficiency with low cortisol production and normal secretion of pituitary hormones other than ACTH. Isolated ACTH deficiency has rare association with Hashimoto's disease which is characterized by autoimmune origin. This suggests the possibility of common autoimmune process affecting both the pituitary and the thyroid gland. We report a case of IAD with Hashimoto's disease in a patient who presented with anorexia,nausea,vomiting and weight loss.

\section{Case report}

A 84 year-old man presented with anorexia,nausea,vomiting and weight loss last 3 months without any apparent cause. His endoscopy revealed a Mallory-weiss tear in esophagus sclerothrapy was performed.

The laboratory test established hypothyroidism with plasma levels of free T3 of $1.89 \mathrm{pg} / \mathrm{ml}$ ( 1.71-3.71), free T4 of $0.47 \mathrm{ng} / \mathrm{ml}(0.7-1.48)$ and high TSH of $19.2 \mathrm{mcIU} / \mathrm{ml}(0.35-1.94)$. The autoimmune antibodies were positive and the patient's level of cortisol was found 1.22 $\mathrm{mcg} / \mathrm{dl}$. The level of ACTH was studied for the separation of the primary and secondary adrenocortical failure, ACTH levels were determined as $3.4 \mathrm{pg} / \mathrm{ml}$. The patient was diagnosed with secondary adrenocortical insufficiency. We examined the other pituitary hormones such as FSH, LH, prolaktin and GH which were in normal limits. DHEA-S level was found $18.7 \mathrm{ug} / \mathrm{dl}$ (E: 80-560). The magnetic resonance of pituitary imaging was normal. Hyrocortisone and L- thyroxine supplemention improved his symptoms.

\section{Conclusion}

This case is educational because, isolated ACTH deficiency is a rare cause of adrenal insufficiency which can associate with Hashimoto's thyroidis that may present with severe digestive symptoms such excessive vomitting. 